\title{
RADON CONCENTRATION ASSESSMENT IN BANK CELLARS IN THREE NIGERIAN CITIES
}

\author{
I. K. Adegunn, ${ }^{1 *}$, B. E. Anyaegbuna ${ }^{2}$, O. A. Olayemi ${ }^{3}$, T. S. Jolayemi ${ }^{4}$ \\ and M. O. Ibiwoye ${ }^{5}$

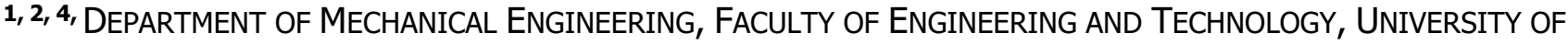 \\ ILORIN, ILORIN, KWARA STATE, NIGERIA. \\ 3, Department of Aeronautics and Astronautics, College of Engineering and TeChnology, KWARA \\ State UniVersity, Malete, KWARA State, NIGERIA. \\ 5, Department of Mechanical Engineering, College of Engineering and TeChnology, Kwara State \\ UNIVERSITY, MALETE, KWARA STATE, NIGERIA. \\ E-mail addresses: ${ }^{1}$ kadegun@unilorin.edu.ng, ${ }^{2}$ benanyaegbuna@yahoo.com, \\ 3olalekan.olayemi@kwasu.edu.ng, ${ }^{4}$ temidayosam2005@yahoo.com, ${ }^{5}$ micheal.ibiwoye@kwasu.edu.ng
}

\begin{abstract}
Cellar workplaces are considered as confined environment with challenging indoor air quality having higher than normal pollutants particularly that of soil gas origin. Radon, a major soil gas, infiltrates and accumulates within indoor spaces and becomes harmful in the absence of ventilation. Radon level in bank basements (cellars) in Ilorin, Lagos and Akure have been sampled and analysed in this study. In Nigeria, most workers in basements are unaware of radon, and there is limited documented research on its health hazards. The survey parameters of radon concentrations were floor types, geographical locations and the influence of atmospheric conditions. Corentium monitor, a continuous, digital radon monitor, temperature meters and Prologue wireless weather station were used for the experiments. Annual average indoor radon concentration for the survey period was $23 \mathrm{~Bq} / \mathrm{m}^{3}$. The calculated mean annual effective doses in basements and different floors were below the recommended ICTR level of $3 \mathrm{mSv} / \mathrm{y}$.
\end{abstract}

Keywords: Indoor air quality, Pollutants, Radon, Ventilation.

\begin{tabular}{clll}
\multicolumn{2}{c}{ Nomenclature } \\
$C_{R n}$ & Radon concentration, $B q / \mathrm{m}^{3}$ & $H$ & Occupancy factor \\
$D$ & Dose conversion factor, $9 \times 10^{-6} \mathrm{mSv} / \mathrm{h} /\left(\mathrm{Bq} / \mathrm{m}^{3}\right)$ & $T$ & Time, $h r$ \\
$E$ & Annual mean effective dose & $F$ & Equilibrium factor (0.4)
\end{tabular}

\section{INTRODUCTION}

Air quality studies in basements have recently generated interest owing to the increased human occupation as against its traditional usage as a utility storage space. These basements are gradually finding wider application as offices, lecture and entertainment theatres, shopping malls, and so on. These current trends therefore have brought to fore issues of indoor air quality in these confined spaces. There is also the issue of low or poor awareness on the health risks of below-grade building and their peculiar challenges of moisture, soil gases and radon intrusion, back drafting and proper ventilation [1]. One of the soil gases that have been of much concern to the health, environmental and building industry is Radon gas. Radon is a proven lung carcinogen for humans [2]. In many countries, exposure to radon is, before medical exposure, the primary source of exposure to ionising radiation [3]. This rise in the indoor air concentration of radon was recognized as a radiation health hazard,

\footnotetext{
* Corresponding author, tel: +234-803-682- 0561
} 
potentially causing an increase in the incidence of lung cancer [4]. The main radon source in most above ground workplaces with high radon concentrations is the soil, but there can also be significant contributions from building materials, groundwater, storage and processing of large amounts of materials with elevated concentrations of radium. Radon is ubiquitous, it is found everywhere in workplaces and dwellings, but levels vary from place to place and over time [4].

Occupied basements with air-tighter built envelopes, are particularly utilised in the Banking industry in Nigeria, where the vault is often located in the basement. These bank basements not only accommodate their vaults but also are substantially used for workspaces for the treasury staff. Basement vaults are listed by Canadian Centre for Occupational Health and Safety as a confined place that require additional safety and health regulation [5]. Money stored in the basements vaults as in the case with the Central Bank of Nigeria buildings and large deposit banks poses additional discomfort and health challenge to workers in these confined spaces. Uneke and Ogbu in 2007 [6] observed that $90 \%$ of Nigerian bank notes in circulation were contaminated with either bacteria or fungi. Indoor air in these particular basements are already contaminated by their contents if the ventilation is not effective and the workers that spend substantial fraction of their time within these confined spaces of the buildings are at risk of contracting Building Related Illness (BRI). Unfortunately, most of these basements vaults are not tested for Radon and other chemical and microbiological infestations in third world countries and in most cases the only protection available to workers in these confined environments is the face mask.

Radon, a typical soil gas normally dissipates harmlessly into outdoor air, but it also flows into buildings through cracks and gaps in the foundation, eventually reaching unsafe levels in lower floors and basements [7]. It becomes an indoor air pollution problem when it penetrates into buildings directly from the soil or is emitted from building materials and accumulates inside the buildings [8]. Radon $\left(222 R_{n}\right)$ is a colourless, odourless, and tasteless radioactive gas formed from radium (226Ra), which is a decay product of Uranium (238U). It has a half-life of 3.8 days, and tends to concentrate in enclosed spaces like underground mines, basements and crawl spaces [9]. ${ }^{222} \mathrm{Rn}$ concentrations in dwellings depend on meteorological and geological conditions, lifestyle, construction materials, and ventilation [10].

Radon is one of the most pervasive and serious global indoor air concerns, organisations such as the International Commission on Radiological Protection (ICRP), the European Radon Association (ERA), the International Atomic Energy Agency (IAEA), the United Nations Scientific Committee on the Effects of Atomic Radiation (UNSCEAR) have made numerous statements on radon gas [11-13] and [4]. They focus on setting radon reference/action levels for radon in air for different building types, producing maps showing areas of high radon potential and incorporating radon preventive measures into new constructions. Many countries, as a result of their numerous studies and interventions, now have active radon programmes in operation. The U.S EPA in 2015[9]recommended taking actions to reduce radon exposure if levels exceed four picocuries per liter of air (4 pCi/L). At the action level of $200 \mathrm{~Bq} / \mathrm{m}^{3}$, there is approximately a $3 \%$ life time risk of developing cancer as a result of radon exposure [9] and [14].

Extensive radon surveys have been carried out in many countries only in dwellings, whereas surveys in workplaces are rather sparse and generally restricted to specific workplaces/activities, for example, schools and caves. The occupational exposure to radon in Nigeria has not generated much study as expected. Few studies have been performed in order to improve the knowledge of radon levels in workplaces with particular attention to schools. Obed, et. al [10] conducted an indoor Radon survey in a university campus of Nigeria; they measured the Radon concentration in 24 offices at the University of Ibadan, Nigeria and found out an average $293.3 \mathrm{~Bq} / \mathrm{m}^{3}$ in the offices. Afolabi, et. al [15] used a Pro 3-series radon detector to determine the radon levels in randomly selected offices at the Obafemi Awolowo University, Ile-Ife; and their results revealed that the radon level obtained in the sampled offices ranged from 0.0 to $5.3 \mathrm{pCi} / \mathrm{L}\left(196 \mathrm{~Bq} / \mathrm{m}^{3}\right)$. The radon concentrations were all found to be within the reference levels of ICRP, but the availability of information on national scale is nonexistent.Of the few studies and surveys of indoor radon concentrations carried out in Nigeria, no systematic study has investigated radon levels in occupied basements. Therefore, this paper seeks to investigate Radon concentrations in selected bank basements and also increase public awareness about the radon hazard to workers in this confined space. 


\section{MATERIALS AND METHODS}

\subsection{Study Areas and Characteristics}

The location areas are Ilorin, Lagos and Akure. Ilorin city occupies an area of about $468 \mathrm{sq} . \mathrm{km}$ and at an elevation of $320 \mathrm{~m}$ above sea level. It is about 300 kilometres away from Lagos and $204 \mathrm{~km}$ from Akure [16].The three cities experience two climatic seasonsthe rainy and dry seasons. The rainy season is between March and November, and the annual rainfall varies from $1000 \mathrm{~mm}$ to $1500 \mathrm{~mm}$ each, with the peaks between September and early October. The study location towns can be located on the map of West African sub region of Africa as shown in Figure 1.

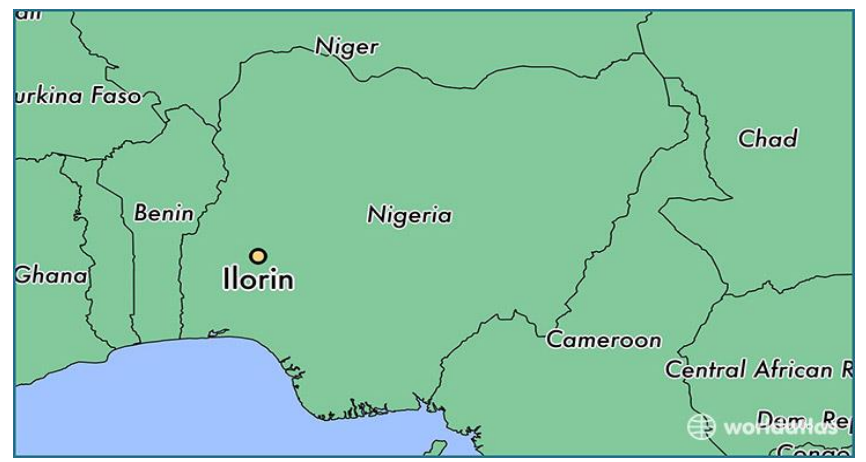

Figure 1: Location map [17]

\subsection{The Study Locations and Measurement Sites}

This experimental study was carried out in three Bank complexes with occupied basements. The basements serve as vaults and office spaces with a daily human occupation of eight hours. The top floors serve as banking halls, offices and conference rooms. The Bank Buildings are perfect examples of complex buildings that utilize only Mechanical Ventilations. Figure 2 shows the layout plan of the Ilorin study location; while Figure 3 is a typical bank cellar/ basement.

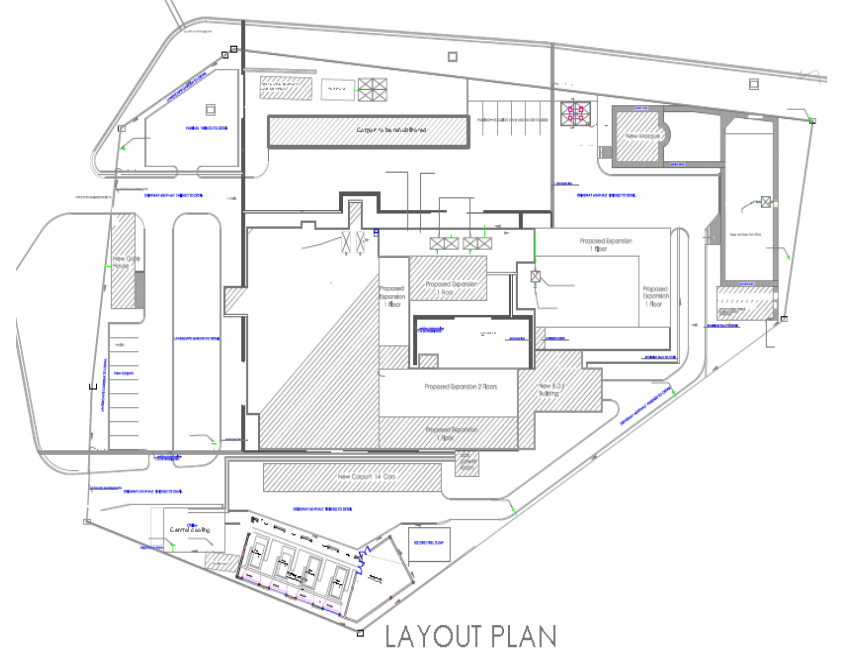

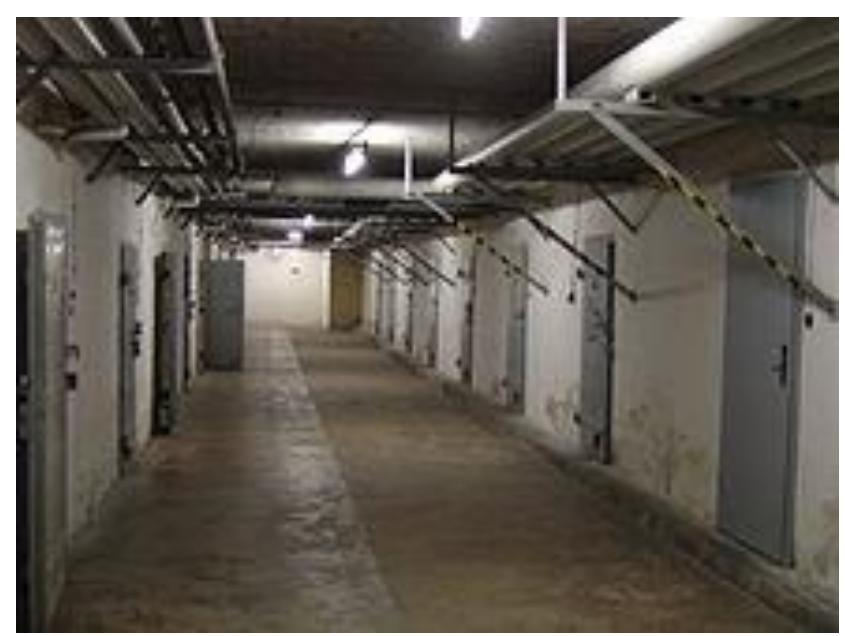

Figure 3: Typical Bank Cellar

\section{A BRIEF DESCRIPTION OF THE EQUIPMENT USED}

The experimental approach involved the collection of data through sensors and data acquisition software from the selected occupied commercial buildings with basements operating only mechanical ventilation. The selected instruments are digital continuous monitoring instruments that enables effective, and flexible measurement of the desired parameters. The instruments are able to monitor continuously Indoor Air Quality (IAQ) parameters, both indoor and outdoor environments, in real-time, thereby eliminating the problems associated with sampling and laboratory analysis.

The Corentium monitor offers two measurements display modes for the Radon concentration, the 'short term' and 'long term' averages. The advantage of the 'short term' mode is the quick response to concentration changes which enables a reading after 24 hours, while the 'long term' mode gives a 7 day average reading with a sensitivity twice as high compared with the 'short term' mode. It has an accuracy level of $\pm 7 \%+0.12 \mathrm{pCi} / \mathrm{L}$ after 24 hours and $\pm 5 \%+0.05 \mathrm{pCi} / \mathrm{L}$ after 7 days. It requires no annual calibrations throughout its useful life, estimated at over 10 years. The radon measuring instrument is of American origin and therefore the concentration of radon in the air was measured in units of picocuries per litre ( $\mathrm{pCi} / \mathrm{L})$. The international system (SI) units of radon measurement is in Becquerel per cubic meter $\left(\mathrm{Bq} / \mathrm{m}^{3}\right)$. One $\mathrm{pCi} / \mathrm{L}$ is equivalent to $37 \mathrm{~Bq} / \mathrm{m}^{3}$. The values are later converted to the unit of $\mathrm{Bq} / \mathrm{m}^{3}$.

Figure 2: Layout of Ilorin Study Location 


\section{EXPERIMENTAL PROCEDURES}

Indoor and outdoor temperature and humidity were monitored with the Prologue Wireless Weather Stations. The weather station comprises of wireless sensors which were placed at predetermined locations within and outside the basements. The measurements were carried out in a total of 12 offices in the banks complexes in Ilorin, Lagos and Akure. The measurements required that a closed space conditioned is maintained 12 hours before commencing testing. This is achieved by ensuring that the continuous radon monitor is in place at the close of work at 5:00pm prior to the start of the days' work at 8:00am in the morning. The test monitor is placed at least $600 \mathrm{~mm}$ above the floor level at a location where it will not be disturbed throughout the duration of the testing. The unit is left on throughout the testing period which runs for a minimum of 48 hrs but gives a short-term result after $24 \mathrm{hrs}$. Some of the measurements were made during the weekends when the offices were closed for two days-Saturdays and Sundays.

Outdoor measurements took place at the beginning and end of each week. Data on 24 h-average outdoor temperature and relative humidity were obtained from the digital wireless weather station. These procedures were conducted in accordance with [18]. The database consists of measurements taken between August 2015 and September 2016.The placement of radon instrumentation inside the vaults were performed by bank company staff, properly instructed on the modalities and operations of the test monitors and provided with appropriate forms for data collection. This is because the vault located within the basement is a confined and secured environment. One of the researchers, however, had some limited access to the vault as a result of the ventilation upgrade being undertaken by his firm for the bank.

\section{RESULTS AND DISCUSSION}

Descriptive statistics (median, mean, standard deviation, range, etc.) have been computed on radon annual averages estimated in the workplaces and adjoining offices. In order to evaluate zonal averages, a single value for each workplace has been calculated. Analytical techniques involving Analysis of Variance (ANOVA), and T-test Statistical Tools, using the Statistical Package for the Social Sciences (IBM Statistics SPSS 21.0) were employed for data analysis.

\subsection{Average Radon Concentration in the Basement Workplaces}

Radon values are expressed in terms of the annual average activity concentration $\left(\mathrm{Bq} / \mathrm{m}^{3}\right)$; the results measured in 3 bank's occupied basements is reported in Table 1. It can be observed that radon annual averages ranged between 0.67 and $107.3 \mathrm{~Bq} / \mathrm{m}^{3}$, with an arithmetic mean of $23.68 \mathrm{~Bq} / \mathrm{m}^{3}$. The variation of radon concentration in the basement workplaces surveyed is shown in Figure 3. The radon values were below the action level of $4 \mathrm{pc} / \mathrm{l}$ stipulated by [9]. The values are also less than the upper value of the ICRP reference levels of $1500 \mathrm{~Bq} / \mathrm{m}^{3}$ for underground workplaces [19].

Table 1: Summary of annual average radon concentration in the basement workplaces

\begin{tabular}{cc}
\hline Summary of & Radon Measurements in \\
Parameters, $\left(\mathrm{Bq} / \mathrm{m}^{3}\right)$ & Workplaces \\
\hline Min & 0.67 \\
Max & 107.3 \\
Mean & 23.68 \\
SD & 16.6 \\
\hline
\end{tabular}

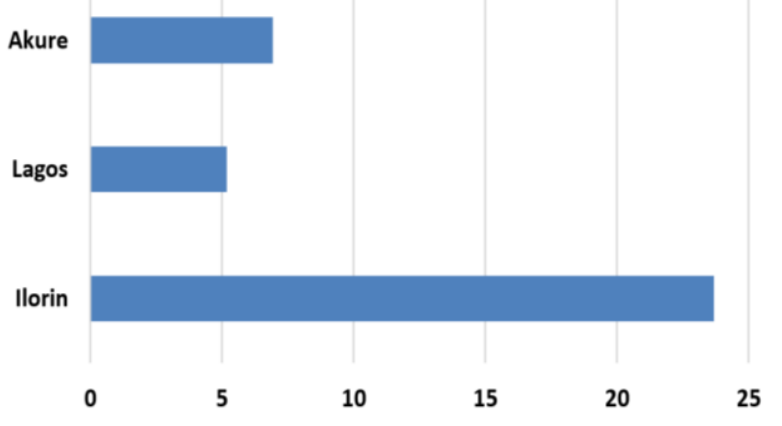

Figure 4: Variation of radon concentration in the basement workplaces of Ilorin, Akure and Lagos.

\subsection{Average Annual Concentration of Radon $\left(\mathrm{Bq} / \mathrm{m}^{3}\right)$ In Underground Workplaces: Analysis of Zonal Distribution.}

Averages have been calculated on the basis of radon values of the banks underground workplaces of the three cities which are spread within two geo-political zone (North-Central and South-West) in Nigeria. The estimation of annual average radon concentration in each bank's workplace was obtained by averaging the results achieved in the underground workplaces of each of the considered city over a thirteen- month testing period. The average radon values in the underground workplaces is given in Figure 4.

It can be observed that the annual radon averages varied from $5.18 \mathrm{~Bq} / \mathrm{m}^{3}$ up to $23.68 \mathrm{~Bq} / \mathrm{m}^{3}$ so that the 
difference in radon levels, can be attributed to local geological characteristics. Interestingly the south west regions, Akure, $\left(6.92 \mathrm{~Bq} / \mathrm{m}^{3}\right)$ and Lagos $\left(5.18 \mathrm{~Bq} / \mathrm{m}^{3}\right)$ showed quite low regional averages when compared with the North-Central zone city of Ilorin $\left(23 \mathrm{~Bq} / \mathrm{m}^{3}\right)$. However much higher radon concentration values $\left(293.3 \mathrm{~Bq} / \mathrm{m}^{3}\right)$ were obtained by [10] in a University of Ibadan campus survey of classrooms and offices.

The results from Ilorin city are in good agreement with previous studies performed in dwellings and wells in Zaria [20]. Ibadan and Zaria are within the South-West and North-West geo-political zones of Nigeria respectively.

Analysis of Variance (ANOVA) was used to test if there is any significant difference between the radon concentrations in Akure, Ilorin, and Lagos. The radon concentration in the three cities are considered significantly different between the radon concentrations in the three locations if $p$-value < 0.05. The F statistics was calculated as 3.072 , at 5 percent level of significance under 2 degrees of freedom, the returned $p$-value of 0.071 was found greater than the level of significance (0.05); $p>0.05$. Thus, there is no significant difference between the radon concentrations in the three selected locations. However, the difference between the radon concentrations in the three selected locations is significant at 0.1 level of significance.

\subsection{Effects of Other Floors on Basement Indoor Radon Concentration}

Table 2 below shows that Ilorin has the highest Radon concentration in the basement and other upper floors.
Akure has the lowest Radon concentration in the $2^{\text {nd }}$ floor, while Lagos has the least Radon concentration across floors except in $2^{\text {nd }}$ floor. More so, Ilorin has the highest mean and standard deviation $\left(11.05 \mathrm{~Bq} / \mathrm{m}^{3}\right.$; $\left.5.882 \mathrm{~Bq} / \mathrm{m}^{3}\right)$, while Lagos has the least $\left(5.45 \mathrm{~Bq} / \mathrm{m}^{3}\right.$, $\left.1.401 \mathrm{~Bq} / \mathrm{m}^{3}\right)$.

The implication of the variation in radon concentration across the floor can be further understood by estimating the radiation dose the workers in the basement and other floors are exposed to by virtue of their locations in the bank building. The effective dose of radon in the Ilorin study location was analyzed as a case study.

\subsection{Effective Dose of Radon (Ilorin)}

The effective dose of radon in $\mathrm{mSv} / \mathrm{y}$ at any location depends upon the occupancy factor. The banks management as a policy allow workers to alternate their work periods on 2-week off and on basis. The bank's basement workers occupancy factor was determind as below:

$40(h / w) \times 26(w k / y r)=1040 h / y r$

The Occupancy factor $(H)$ :

$$
H=1040 h / 8760 h=0.12
$$

The bank's workers in other floors will have an occupancy factor determind as below:

$$
40(h / w k) \times 44(w k / y r)=1760(h / y r)
$$

The Occupancy factor $(H)$

$$
H=1760 h / 8760 h=0.20
$$

The annual mean effective dose to the occupants of these offices due to exposure to radon and its progeny was estimated by following [13].

$$
E=C_{R n} \times H \times F \times D \times T
$$

Table 2: Radon Concentration by Geographical Locations

\begin{tabular}{ccccccc}
\hline $\begin{array}{c}\text { Location } \\
\text { Floor }\end{array}$ & $\begin{array}{c}\text { Basement } \\
\left(\mathrm{Bq} / \mathrm{m}^{3}\right)\end{array}$ & $\begin{array}{c}\text { Ground } \\
\text { Floor }\left(\mathrm{Bq} / \mathrm{m}^{3}\right)\end{array}$ & $\begin{array}{c}1 \text { 1st } \\
\text { Floor }\left(\mathrm{Bq} / \mathrm{m}^{3}\right)\end{array}$ & $\begin{array}{c}2 \text { nd Floor } \\
\left(\mathrm{Bq} / \mathrm{m}^{3}\right)\end{array}$ & $\begin{array}{c}\text { Mean } \\
\left(\mathrm{Bq} / \mathrm{m}^{3}\right)\end{array}$ & $\begin{array}{c}\text { STD } \\
\left(\mathrm{Bq} / \mathrm{m}^{3}\right)\end{array}$ \\
\hline Akure & 6.92 & 5.62 & 5.15 & 2.21 & 7.35 & 3.313 \\
Ilorin & 23.68 & 11.84 & 5.18 & 5.92 & 11.05 & 5.882 \\
Lagos & 5.18 & 4.81 & 4.07 & 3.68 & 5.45 & 1.401 \\
\hline
\end{tabular}

Table 3: The annual mean effective dose to the occupants in the floors (Ilorin)

\begin{tabular}{ccc}
\hline Space type & $\begin{array}{c}\text { Radon Concentration } \\
\left(\mathrm{C}_{\mathrm{Rn}}\right)\left(\mathrm{Bq} / \mathrm{m}^{3}\right)\end{array}$ & Effective Dose $(\mathrm{E}),(\mathrm{mSv} / \mathrm{y})$ \\
\hline Basement & 23.68 & 0.0896 \\
Ground Floor & 11.84 & 0.0747 \\
First Floor & 5.18 & 0.0326 \\
Second Floor & 5.92 & 0.0377 \\
\hline
\end{tabular}


With this occupancy, the exposure of workers to radon is reduced in the case of maximum radon concentration (equals to $107 \mathrm{~Bq} / \mathrm{m}^{3}$ ), the effective dose was calculated to be $0.4049 \mathrm{mSv} / \mathrm{y}$. The reduced occupancy time gives rise to low doses in the case of bank's basement staff when compared to the staff occupying the ground floor with a reduced radon concentration $\left(11.84 \mathrm{~Bq} / \mathrm{m}^{3}\right)$, but with almost an equivalent annual mean of radon effective dose exposure of $0.0747 \mathrm{mSv} / \mathrm{y}$ and $0.0896 \mathrm{mSv} / \mathrm{y}$ in the ground floor and basement respectively. The radon concentration and effective dose were found to be lower in the first floor than the second floor. This can be explained by the space conditions of the measured floors. The first floor is a mezzanine floor which allows higher air flow from the mechanical ventilations system than is obtainable at the second floor. Recent epidemiological findings from residential studies demonstrate a statistically significant increase of lung cancer risk from prolonged exposure to indoor radon even at low level of exposure [3].

\subsection{The Effect of Weather Condition at Different Geographical Locations}

Indoor air qualities are greatly impacted by the air quality outside of the buildings. The time that the data were taken was divided between dry and wet seasons. Dry season has been set between October and April, and Wet set between May and September.
A weather station was setup 20 meters from the building to record all relevant weather data hourly. The result of the seasons are as shown in Tables 4, 5, 6 and 7. The tables display the maximum radon concentration, humidity, air temperature and wind speed. Table 6 and 7 show that Ilorin has the highest Radon concentration in both dry and wet seasons, followed by Akure, while Lagos has the least Radon concentration. More so, Radon Concentrations in Ilorin has the highest mean and standard deviation. The table shows further that the Radon concentrations in dry season across the three geographical locations are higher than those of the wet season.

The humidity in Lagos is highest in the two seasons, while the air temperature and wind speed varies across the cities. The air temperature appears to have little effect on the radon concentration, while humidity has an inverse relationship with the radon concentration which reduces as the humidity increases. The result is in agreement with the findings of Schumann et. al [21] that the most important factors appear to be precipitation (as it affects soil moisture conditions) and barometric pressure. They further stated that radon transport is generally inhibited by soil moisture because water tends to block soil pores, reducing the gas permeability of the soil resulting in lower values of radon in the wet seasons.

Table 4: Dry Season (October-April)

\begin{tabular}{lllll}
\hline & Max Radon $\left(\mathrm{Bq} / \mathrm{m}^{3}\right)$ & Humidity $(\%)$ & Air Temp. $\left({ }^{\circ} \mathrm{C}\right)$ & Wind Speed $(\mathrm{m} / \mathrm{s})$ \\
\hline Ilorin & 107.8 & 56.38 & 32.46 & 1.07 \\
Lagos & 17.9 & 78 & 27.8 & 0.44 \\
Akure & 21.51 & 62.3 & 31.5 & 1.94 \\
\hline
\end{tabular}

Table 5: Outdoor - Wet Season (May-September)

\begin{tabular}{lllll}
\hline & Max Radon $\left(\mathrm{Bq} / \mathrm{m}^{3}\right)$ & Humidity $(\%)$ & Air Temp. $\left({ }^{\circ} \mathrm{C}\right)$ & Wind Speed, $(\mathrm{m} / \mathrm{s})$ \\
\hline Ilorin & 46.8 & 68.38 & 28.0 & 0.77 \\
Lagos & 11.07 & 86.38 & 32.46 & 0.33 \\
Akure & 14.81 & 71.5 & 27.4 & 0.54 \\
\hline
\end{tabular}

Table 6: Radon Concentration by Atmospheric Conditions

\begin{tabular}{lrrr}
\hline Location/Season & Dry Season & Mean & STD \\
\hline Akure & 21.51 & 12.16 & 6.350 \\
Ilorin & 107.8 & 34.30 & 17.500 \\
Lagos & 17.9 & 10.99 & 6.915 \\
\hline
\end{tabular}

Table 7: Radon Concentration by Atmospheric Conditions

\begin{tabular}{lccc}
\hline Location/Season & Wet Season & Mean & STD \\
\hline Akure & 14.81 & 8.13 & 3.580 \\
Ilorin & 46.80 & 20.45 & 7.700 \\
Lagos & 11.07 & 6.79 & 2.645 \\
\hline
\end{tabular}


The t-test statistics was calculated as 1.725 , at 5 percent level of significance under 4 degrees of freedom, the returned $p$-value of 0.160 was found greater than the level of significance (0.05); $p>0.05$. Thus, it is concluded that there is no significant difference between the radon concentration in dry and wet seasons.

\section{CONCLUSION}

This study reports the results of a survey carried out to evaluate the radon concentration in basement workplaces. The survey covered 12 bank workplaces in the three cities. In each workplace, continuous radon devices were exposed for a period of 13 months. As expected, radon concentration is not uniform in the cities. In the basement workplaces of the sampled cities, low radon annual averages have been found higher in the north-central geopolitical zones of Nigeria. The analysis of variance among the cities and within banks floors workplaces shows that the spread of radon values has no strong relationship with the respective radon average concentration. The results of the present work confirms the presence of indoor radon in basement workplaces and the need to pay attention to the radiological protection of employees working in basements.

The average annual activity concentration limit for occupational exposure as set by IAEA is 1000 $\mathrm{Bq} / \mathrm{m}^{3}$; however, exposure limits is expected to reduce gradually to $300 \mathrm{~Bq} / \mathrm{m}^{3}$ for both workers and members of the public[22].Nigeria is yet to establish a reference level for the protection of workers from radon exposure in workplaces.

\section{REFERENCES}

[1] U.S. Environmental Protection Agency. "Assessment of Risks from Radon in Homes", Washington, DC: U.S. Environmental Protection Agency; EPA 402-R-03003,https://www.epa.gov/sites/production /files/2015-05/documents/402-r-03-003.pdf, Accessed on May 15, 2018.

[2] International Agency for Research on Cancer. "IARC Monographs on the Evaluation of Carcinogenic Risks to Humans".https://monographs.iarc.fr/ENG/Mon ographs/vol78/mono78.pdf, Accessed on July 20, 2018.

[3] Heads of European Radiological Protection Competent Authority (HERCA). "Report on the HERCA

Nigerian Journal of Technology,
Workshop"http://www.herca.org/uploaditems/ documents $151020 \% 20$ -

\%20WS\%20Radon/Radon\%20WS\%20final\%2 OReport.pdf. Accessed 21 March, 2017.

[4] International Atomic Energy Agency."Radiation protection against radon in work places other than Mines". http://wwwpub.iaea.org/MTCD/publications/PDF/Pub1168 _web.pdf Accessed on 21 February, 2017.

[5] Canadian Centre for Occupational Health and Safety (CCOHS). Confined space. www.ccohs.ca/oshanswers/confinedspace/govt .htmlAccessed 5 November, 2017.

[6] Uneke, C. and Ogbu, O. "Potential for parasite and bacterial transmission by paper currency in Nigeria", Journal of Environmental Health, Vol.69, Number 9, 2007, pp 54-62.

[7] Amissah, P. K. (2005). "Indoor air quality: Combining air humidity with construction moisture", University of Strathclyde, 2005.

[8] Grimsrud, D. T., Hadlich, D. E. and Krafthefer, B. "University of Minnesota Radon in Institutional Buildings: the impact of Conservation Strategies Systems on Radon Concentrations", https://aceee.org/files/proceedings/1994/data/ papers/SS94_Panel9_Paper16.pdf.

[9] Occupational Safety and Health Administration. (2011)"Indoor Air Quality in Commercial and Institutional

Buildings".https://www.osha.gov/Publications/3 430indoor-air-quality-sm.pdf.Accessed 21 October, 2018.

[10] Obed, R., Lateef, H. and Ademola, A. (2010). "Indoor radon survey in a university campus of Nigeria", Journal of Medical Physics/Association of Medical Physicists of India, Vol. 35, Number 4, 2010, pp 242.

[11] ICRP Publication 67: Age-dependent Doses to Members of the Public from Intake of Radionuclides: Part 2 Ingestion Dose Coefficients Vol. 67, 1994 (Elsevier Health Sciences).

[12] European Radon Association. "Improving Awareness and Reducing the Risk of Radon Exposure Across Europe". http://radoneurope.org/index.php/scientificpublications/

[13] United Nations Scientific Committee on Effects of Atomic Radiation. "Sources and Effects of Ionizing Radiation. https://www.unscear. org/docs/publications/2000/UNSCEAR_2000_R 
eport_Vol.I.pdf. Accessed on 20th February, 2018.

[14] Turk, B., Hughes, J., and Center, S. R. R. T. "Exploratory study of basement moisture during operation of ASD radon control systems" http://www. epa.gov/radon/pubs/index. html., Accessed on Dec., 10, 2018.

[15] Afolabi, O. T., Esan, D. T., Banjoko, B., Fajewonyomi, B.A., Tobih, J.E. and Olubodun, B.B., BMC Research Notes, "Radon level in a Nigerian University Campus", Vol. 8, Number 1, 2015, pp. 677.

[16] Tunde, A., Adeleke, E. and Adeniyi E. "Impact of Climate Variability on Human Health in Ilorin, Nigeria", Environment and Natural Resources Research, Vol.3, Number 1, 2013, pp 127.[17] www.worldatlas.com Accessed on 4July, 2014.

[18] EPA 402-R-03-003."Quality Assurance and Quality Control Plan for the Measurement of Indoor Radon Concentrations with ProChek
Activated Charcoal Test Kits". https://www.inspectdm.com/wpcontent/uploads/2017/07/QC-QC-Plan-InspectDes-Moines.pdf.

[19] International Commission on Radiological Protection (ICRP). (2010) Annual Report ICRP reference 4812-3000-2698 2011-0.

[20] Garba, N., Rabirsquo , N., Dewu, B., Sadiq, U and Yamusa, Y. "Radon assessment in ground water sources from Zaria and environs, Nigeria," International Journal of Physical Sciences, Vol. 8, 2013, pp. 1983-1987.

[21] Schumann, R. R., Owen, D. E., Asher-Bolinder, S. "Factors Affecting Soil-Gas Radon Concentrations at a Single Site in the Semiarid Western U.S", In Proc. of the 1988 EPA Symposium on Radon and Radon Reduction Technology 2. Publication.

[22] https://www-pub.iaea.org/MTCD/publications /PDF/Pub1183_web.pdf. 